Jurnal Agro 8(1), 2021

\title{
PENGARUH KONSENTRASI Si BIOGENIK DAN N-TOTAL TERHADAP PERTUMBUHAN DAN KONSENTRASI NITRAT TANAMAN SELADA HIDROPONIK
}

\section{EFFECT OF Si-BIOGENIC AND N-TOTAL CONCENTRATIONS TO THE GROWTH AND NITRATE CONCENTRATION OF HYDROPONIC LETTUCE}

\author{
Salamet Ginandjar, Budy Frasetya Taufik Qurrohman*, Panji Rahmatullah \\ Jurusan Agroteknologi, Fakultas Sains dan Teknologi, UIN Sunan Gunung Djati \\ Jl. A.H. Nasution No. 105 Bandung 40614
}

Korespondensi : budyftq1682@gmail.com

Diterima : 11 Maret 2021 / Disetujui : 19 Juli 2021

\begin{abstract}
ABSTRAK
Tanaman selada merupakan sayuran yang dikonsumsi dalam bentuk segar. Karakteristiknya sebagai tanaman akumulator nitrat perlu diimbangi pemupukan $\mathrm{N}$ dan aplikasi Silika (Si) sesuai kebutuhan tanaman. Penelitian ini bertujuan untuk mempelajari interaksi ekstrak silika sekam padi (ESSP) dan $\mathrm{N}$-total, serta memperoleh konsentrasi ESSP dan $\mathrm{N}$-total yang tepat untuk menghasilkan panen selada yang tinggi tetapi aman bagi kesehatan. Rancangan penelitian yang digunakan adalah Rancangan Acak Lengkap Faktorial, faktor pertama adalah konsentrasi ESSP $(0$ ppm, 30 ppm, 60 ppm, 90 ppm) dan faktor kedua adalah konsentrasi N-total (100 ppm, 200 ppm, 300 ppm), setiap kombinasi perlakuan diulang 3 kali. Parameter yang diamati yaitu tinggi tanaman 35 hari setelah tanam (HST), luas daun, berat kering tanaman, berat segar tanaman, kandungan nitrat pada daun selada. Data dianalisis dengan analisis varians taraf $5 \%$ dilanjutkan dengan Uji Jarak Berganda Duncan pada taraf nyata 5\%, sedangkan parameter kandungan nitrat dianalisis secara deskriptif. Berdasarkan hasil analisis varians konsentrasi ESSP dan konsentrasi $\mathrm{N}$-total berinteraksi pada tinggi tanaman dan berpengaruh mandiri terhadap berat kering tanaman dan berat segar tanaman. Aplikasi ekstrak silika sekam padi $30 \mathrm{ppm}$ meningkatkan hasil panen $28 \%$ lebih tinggi dan menurunkan $12 \%$ kandungan nitrat tanaman selada pada $\mathrm{N}$ total 100-300 ppm.
\end{abstract}

Kata kunci: efisiensi nitrogen, fotosintat, silika

\begin{abstract}
Lettuce is a freshly consumed vegetable. Its characteristics as a nitrate accumulator plant need to be balanced with $\mathrm{N}$ fertilization and Silica (Si) applications according to the plant required. This research aimed to study the interaction between rice husk silica extract (ESSP) and total $\mathrm{N}$ to obtain the right ESSP and total $\mathrm{N}$ concentrations to produce high yield lettuce and safely consumed it. This study used a factorial completely randomized design. The first factor was ESSP concentrations ( 0 ppm, 30 ppm, $60 \mathrm{ppm}, 90 \mathrm{ppm}$ ) and the second factor was total $\mathrm{N}$ concentrations (100 ppm, 200 ppm, 300 ppm). Each treatment combination was repeated 3 times. The parameters observed were plant height in 35 days after planting, leaf area, plant dry weight, fresh plant weight, and nitrat e content in lettuce leaves. The data were analyzed by
\end{abstract}

ISSN : 2407-7933

Cite this as: Ginandjar, S., Qurrohman, B.F.T. \& Rahmatullah, P. (2021). Pengaruh konsentrasi Si biogenic dan $\mathrm{N}$-total terhadap pertumbuhan dan konsentrasi nitrat tanaman selada hidroponik. Jurnal Agro, 8(1), 130-141. https://doi.org/10.15575/10959 
analysis of variance at the $5 \%$, and post-test by DMRT at the $5 \%$ significant level, the nitrate content used descriptive analysis. Based on the analysis of variance, ESSP concentration and total $\mathrm{N}$ concentration interacted on plant height. The ESSP concentration and total $\mathrm{N}$ concentration independently affected plant dry weight and fresh plant weight. Application of 30 ppm rice husk silica extract increased $28 \%$ higher yield and decreased $12 \%$ nitrate content of lettuce plants at N-total of 100-300 ppm.

Keywords: nitrogen efficiency, photosynthate, silica

\section{PENDAHULUAN}

Tanaman selada merupakan tanaman yang umumnya dikonsumsi dalam bentuk segar. Untuk menjaga kualitas produksi dan kesehatan konsumen sistem budidaya selada secara hidroponik menjadi pilihan (Frasetya et al., 2018). Budidaya secara hidroponik memungkinkan setiap aspek yang berpengaruh terhadap produktivitas dikelola dengan baik. Tanaman selada merupakan tanaman yang memiliki akumulasi nitrat sangat tinggi (hyper accumulator) $>2500 \mathrm{mg} \mathrm{kg}^{-1}$ (ppm). Negara di Eropa seperti Jerman dan Belgia mensyaratkan nitrat dalam daun selada tidak melebihi 2500-3500 $\mathrm{mg} \mathrm{kg}^{-1}$. Konsentrasi nitrat yang berlebihan dalam tubuh manusia dapat menyebabkan gangguan kesehatan (Ikemoto et al., 2002).

Konsentrasi nitrat pada tanaman selada dipengaruhi oleh pupuk nitrogen (pemupukan N) dan intensitas cahaya (Anjana et al.,2007). Akumulasi nitrat pada tanaman selada tidak hanya terjadi pada tanaman selada yang dibudidayakan secara hidroponik. Kandungan nitrat pada tanaman selada yang dibudiayakan di tanah (konvensional) kandungan nitratnya akan tinggi apabila diberikan pemupukan $\mathrm{N}$ secara berlebihan. Strategi pengaturan pemupukan $\mathrm{N}$ dalam nutrisi hidropnik dapat dilakukan namun konsentrasi nitrat pada tanaman tidak hanya dipengaruhi pemupukan $\mathrm{N}$. Intensitas cahaya mempengaruhi konsentrasi nitrat pada daun (Fu et al., 2012). Unsur Silika (Si) merupakan unsur fungsional yang dapat meningkatkan pertumbuhan tanaman selada. Hasil penelitian Gottardi et al. (2012) menunjukkan bahwa tanaman selada yang diberi tambahan unsur $\mathrm{Si}$ kualitas dan kuantitas hasil panen lebih tinggi dibandingkan dengan tanpa aplikasi Si. Aplikasi Si selain dapat meningkatkan pertumbuhan dan hasil panen tanaman selada juga dapat menurunkan kandungan nitrat pada tanaman selada. Peran unsur Si dalam menurunkan kandungan nitrat menurut Xie et al. (2014) karena unsur Si mampu meningkatkan metabolisme tanaman sehingga efisiensi unsur hara $\mathrm{N}$ selama proses fotosintesis meningkat (photosynthetic nitrogen use efficiency).

Sumber Si yang tersedia cukup banyak di Indonesia adalah sekam padi. Sekam padi merupakan sumber Si yang berasal dari tanaman (Si biogenik). Si biogenik memiliki sifat $10^{2}$ sampai $10^{4}$ kali mudah larut dibandingkan dengan mineral silikat (Haynes, 2017). Potensi Si dalam sekam padi menurut Dobermann and Fairhurst (2000) adalah $10 \%$ dari biomassa tanaman padi. Kandungan Si pada sekam padi dapat dimanfaatkan oleh tanaman setelah mengalami proses dekomposisi (pengomposan) ataupun dengan metode ekstraksi. 
Metode ekstraksi merupakan metode yang lebih cepat dibandingkan dengan pengomposan. Selain pertimbangan waktu dengan metode ekstraksi aplikasi Si dapat dilakukan dengan cara disemprotkan maupun dilarutkan ke dalam nutrisi tanaman tanpa mengganggu sistem hidroponik. Metode ekstraksi silika yang dapat digunakan mengacu pada prosedur dari Suka et al. (2008) dan Frasetya et al. (2019) hasil dari proses ekstraksi ini menghasilkan pupuk Si yang dikenal dengan ekstrak silika sekam padi (ESSP).

Perbaikan manajemen pemupukan tanaman selada hidroponik dengan pemberian ekstrak silika sekam padi (ESSP) dan konsentrasi $\mathrm{N}$ total dalam nutrisi hidroponik diharapkan dapat meningkatkan produktivitas hasil panen dan kualitas hasil panen tanaman selada yang dapat diterima oleh pasar domestik maupun Internasional. Konsentrasi $\mathrm{N}$-total dalam formulasi nutrisi hidroponik merupakan unsur hara makro yang digunakan sebagai dasar penentu konsentrasi unsur hara makro lainnya (Frasetya et al., 2021). Penelitian ini bertujuan untuk mempelajari interaksi aplikasi ESSP dan konsentrasi $\mathrm{N}$ total, dan memperoleh konsenstrasi ESSP dan $\mathrm{N}$ total untuk menghasilkan produktivitas lebih tinggi dengan kandungan nitrat sesuai dengan ambang batas kemanan pangan Uni Eropa $2500-3500 \mathrm{mg} \mathrm{kg}^{-1}$.

\section{BAHAN DAN METODE}

Penelitian dilaksanakan pada bulan Februari-Maret 2019 di screen house Fakultas Pertanian Universitas Padjadjaran, Ciparanje, Jatinangor, Kabupaten Sumedang Provinsi Jawa Barat. Lokasi penelitian berada $\pm 700 \mathrm{~m}$ diatas permukaan laut (dpl).
Peralatan yang digunakan dalam penelitian ini yaitu: electrical conductivity meter (EC meter), $\mathrm{pH}$ meter, gelas ukur, timbangan, panci, kompor, saringan, ember, aerator dan bak nutrisi hidroponik. Bahanbahan digunakan yaitu: larutan hara $A$ $\left(\mathrm{KNO}_{3}, \mathrm{CaNO}_{3} \cdot \mathrm{NH}_{4}, \mathrm{CaCO}_{3}\right.$, dan Fe-EDTA), larutan hara $\mathrm{B}\left(\mathrm{K}_{2} \mathrm{SO}_{4}, \mathrm{KH}_{2} \mathrm{PO}_{4}, \mathrm{MgSO}_{4}\right.$, $\mathrm{MnSO}_{4}, \mathrm{CuSO}_{4}, \quad \mathrm{Zn}-\mathrm{Edta}, \mathrm{H}_{3} \mathrm{BO}_{3}$, dan $\left(\mathrm{NH}_{4}\right) 6 \mathrm{MO}_{7} \mathrm{O}_{24} \cdot 4 \mathrm{H}_{2} \mathrm{O}$,), sekam padi, $\mathrm{KOH}$, asam salisilat, aquades, benih selada Varitas Grand Rapid dan rockwool.

Metode penelitian yang digunakan adalah metode penelitian eksperimen. Rancangan percobaan yang digunakan merupakan rancangan acak lengkap faktorial. Faktor pertama yaitu konsentrasi Ekstrak Silika Sekam Padi (ESSP) terdiri dari empat taraf perlakuan yaitu: $\mathrm{s} 0=0 \mathrm{ppm}$ (tanpa ESSP), s1= $30 \mathrm{ppm}, \mathrm{s} 2=60 \mathrm{ppm}$ dan s3 $=90 \mathrm{ppm}$. Faktor kedua yaitu konsentrasi $\mathrm{N}$-total yaitu $\mathrm{n} 1=100 \mathrm{ppm}, \mathrm{n} 2=200 \mathrm{ppm}$ dan n3 $=300 \mathrm{ppm}$. Terdapat 12 kombinasi percobaan dan setiap kombinasi diulang sebanyak tiga kali sehingga diperoleh 36 unit satuan percobaan. Satu unit percobaan terdiri dari empat tanaman selada, sehingga total populasi tanaman adalah 144 tanaman.

Parameter pertumbuhan yang diamati dalam penelitian ini yaitu tinggi tanaman 35 hari setelah tanam (HST), luas daun 35 HST, berat kering tanaman, berat segar tanaman dan satu komponen kualitas yaitu kandungan nitrat pada daun selada. Metode analisis yang digunakan adalah analisis varians pada $\alpha=5 \%$. Hasil analisis varians kemudian dilanjutkan dengan uji Duncan pada taraf $5 \%$. Komponen kualitas yaitu konsentrasi nitrat pada daun selada dianalisis secara deskriptif dalam bentuk grafik.

Penelitian ini dilaksanakan sesuai dengan tahapan berikut yaitu: 
1. Pembuatan ekstrak silika sekam padi sesuai dengan prosedur yang dilaksanakan oleh Suka et al. (2008) dan Frasetya et al. (2019) sekam padi ditepungkan terlebih dahulu atau dihaluskan dengan menggunakan mesin penepung kemudian ke dalam panci dimasukkan $50 \mathrm{~g}$ sekam padi, ditambahkan $100 \mathrm{ml}$ air dan $\mathrm{KOH}$ 1,5\%, selanjutnya dipanaskan sampai mendidih kemudian diangkat dan didinginkan, setelah dingin disaring untuk memisahkan butiran tepung agar nosel sprayer tidak tersumbat pada saat aplikasi.

2. Pembuatan bak nutrisi hidroponik rakit apung dengan ukuran bak $20 \times 15 \times 10 \mathrm{~cm}$ dengan jarak tanam $10 \times 15 \mathrm{~cm}$ setiap bak terdiri dari 4 buah tanaman. Bak kemudian ditutup dengan styrofoam yang telah dilubangi sesuai dengan jarak tanam yang ditentukan $10 \mathrm{~cm} \times 15 \mathrm{~cm}$.

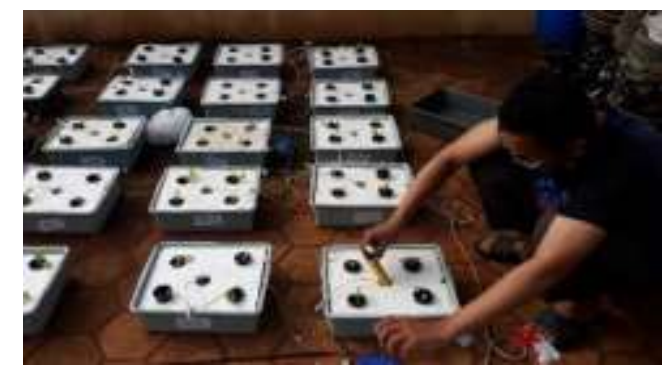

Gambar 1 Instalasi hidroponik rakit apung yang digunakan dalam penelitian

3. Pembuatan nutrisi $A B$ mix sesuai perlakuan dengan $N$ total $100 \mathrm{ppm}, 200$ ppm dan 300 ppm. P (75 ppm), K(325 ppm), $\mathrm{Ca}(175$ ppm), Mg(62 ppm), S(129 ppm), $\mathrm{Fe}(5 \mathrm{ppm}), \mathrm{Mn}(2 \mathrm{ppm}), \mathrm{Cu}(0,1$ ppm), Zn(0,3 ppm), B(0,7 ppm) dan Mo(0,05 ppm). Pembuatan $A B$ mix diawali dengan proses penimbangan senyawa kimia $\mathrm{CaCO}_{3}, \mathrm{KNO}_{3}$ dan FeEDTA ketiga bahan ini dicampurkan sebagai larutan pekat A menjadi larutan sebanyak 5 liter. Larutan pekatan $\mathrm{B}$ terdiri dari $\mathrm{KH}_{2} \mathrm{PO}_{4},\left(\mathrm{NH}_{4}\right)_{2} \mathrm{SO}_{4}, \mathrm{~K}_{2} \mathrm{SO}_{4}$, $\mathrm{MgSO}_{4} .7 \mathrm{H}_{2} \mathrm{O}, \mathrm{MnSO}_{4} .7 \mathrm{H}_{2} \mathrm{O}, \mathrm{CuSO}_{4} .5 \mathrm{H}_{2} \mathrm{O}$, $\mathrm{ZnSO}_{4} .7 \mathrm{H}_{2} \mathrm{O}, \mathrm{H}_{3} \mathrm{BO}_{3},\left(\mathrm{NH}_{4}\right)_{6} \mathrm{Mo}_{7} \mathrm{O}_{24} .4 \mathrm{H}_{2} \mathrm{O}$ semua bahan larutan pekatan $\mathrm{B}$ kemudian dilarutkan sampai diperoleh volume 5 liter.

4. Tahap penyemaian dilaksanakan pada media tanah, pupuk kandang dan sekam bakar dengan perbandingan 1:1:1. Setelah 14 hari penyemaian, bibit dipindah tanam ke media rockwool. Bibit selada dibersihkan akarnya dengan menggunakan air bersih. Pemberian nutrisi hidroponik $A B$ mix berdasarkan pada penelitian Frasetya et al. (2018) 1$14 \mathrm{HST} \mathrm{EC}=1,7 \mathrm{mS} \mathrm{cm}^{-1}$ dan 14-35 HST $\mathrm{EC}=2,4 \mathrm{mS} \mathrm{cm}^{-1}$.

5. Aplikasi ESSP disesuaikan dengan konsentrasi perlakuan dan diberikan pada 7 HST, 21 HST dan 28 HST dengan dosis $2,8 \mathrm{ml}$ per tanaman.

6. Pengukuran suhu dan kelembaban udara di dalam screen house dilaksanakan pada pada pukul 07.00, 13.00 dan 18.00 WIB. Pengukuran intensitas cahaya matahari dengan lux meter dilaksanakan di awal penelitian.

7. Pemeliharaan dilakukan sampai dengan panen pada 35 HST.

8. Total populasi tanaman pada penelitian ini adalah 144 tanaman, sebanyak 48 tanaman digunakan sebagai sampel analisis nitrat pada tanaman dan sisanya sebanyak 96 tanaman digunakan untuk analisis berat kering tanaman.

\section{HASIL DAN PEMBAHASAN}

Hasil analisis varians pada taraf $\alpha=5 \%$ diperoleh hasil bahwa interaksi antara faktor ekstrak silika sekam padi (ESSP) dan 
konsentrasi $\mathrm{N}$ total terjadi pada parameter tinggi tanaman 35 hari setelah tanam (HST). Sedangkan pengaruh mandiri kedua faktor terjadi pada parameter berat kering tanaman (BKT) dan berat segar tanaman (BST). Pada parameter luas daun kedua faktor tidak berpengaruh mandiri maupun pengaruh interaksi.

Tabel 1 Hasil analisis varians pada setiap parameter pertumbuhan tanaman selada

\begin{tabular}{lcccc}
\hline \multirow{2}{*}{ Parameter } & \multicolumn{3}{c}{ Nilai Probabilitas (p-value) } & \multirow{2}{*}{ KK (\%) } \\
\cline { 2 - 4 } & $\mathrm{S}$ & $\mathrm{N}$ & $\mathrm{S} \times \mathrm{N}$ & \\
\hline Tinggi Tanaman 35 HST & $0,00^{*}$ & $0,43^{\text {tn }}$ & $0,03^{*}$ & 9,46 \\
Luas Daun 35 HST & $0,36^{\text {tn }}$ & 0,32 tn & $0,39^{\text {tn }}$ & 4,24 \\
Berat Kering Tanaman & $0,04^{*}$ & $0,00^{*}$ & $0,63^{\text {tn }}$ & 14,34 \\
Berat Segar Tanaman & $0,04^{*}$ & $0,00^{*}$ & $0,07^{\text {tn }}$ & 6,23 \\
\hline
\end{tabular}

Keterangan: KK= Koefisien keragaman $\mathrm{S}=$ Faktor ekstrak silika sekam padi, $\mathrm{N}=$ faktor konsentrasi $\mathrm{N}=$ total $S x N=$ interaksi antara faktor $S$ dan faktor $N .{ }^{*}=$ berpengaruh nyata $(p<0,05)$, $t n=$ tidak nyata $(p>0,05)$

\section{Tinggi Tanaman $(\mathrm{cm})$}

Hasil analisis varians menunjukkan faktor konsentrasi $\mathrm{N}$ total dan konsentrasi ESSP berinteraksi mempengaruhi parameter tinggi tanaman (Tabel 2). Hasil pengamatan tinggi tanaman menunjukkan tinggi tanaman yang diaplikasikan ESSP pada taraf $\mathrm{N}$-total 100-300 ppm menghasilkan rata-rata tinggi tanaman 32,92-49 $\mathrm{cm}$ sedangkan rata-rata tinggi tanaman tanpa aplikasi ESSP 34$39,42 \mathrm{~cm}$.

Tabel 2 Hasil uji Duncan rata-rata tinggi tanaman 35 HST

\begin{tabular}{cccc}
\hline Konsentrasi & \multicolumn{3}{c}{ Konsentrasi N-Total } \\
\cline { 2 - 4 } ESSP & $\mathrm{n} 1(100 \mathrm{ppm})$ & $\mathrm{n} 2(200 \mathrm{ppm})$ & $\mathrm{n} 3(300 \mathrm{ppm})$ \\
\hline $\mathrm{s} 0(0 \mathrm{ppm})$ & $34 \mathrm{a}$ & $39,5 \mathrm{a}$ & $37,5 \mathrm{a}$ \\
& $\mathrm{A}$ & $\mathrm{A}$ & $\mathrm{AB}$ \\
$\mathrm{s} 1(30 \mathrm{ppm})$ & $49 \mathrm{~b}$ & $39,5 \mathrm{a}$ & $40,33 \mathrm{a}$ \\
& $\mathrm{B}$ & $\mathrm{A}$ & $\mathrm{B}$ \\
$\mathrm{s} 2(60 \mathrm{ppm})$ & $35,75 \mathrm{a}$ & $39,5 \mathrm{a}$ & $35,75 \mathrm{a}$ \\
& $\mathrm{A}$ & $\mathrm{A}$ & $\mathrm{AB}$ \\
$\mathrm{s} 3(90 \mathrm{ppm})$ & $35,25 \mathrm{a}$ & $33,25 \mathrm{a}$ & $32,91 \mathrm{a}$ \\
& $\mathrm{A}$ & $\mathrm{A}$ & $\mathrm{A}$ \\
\hline
\end{tabular}

Keterangan: Angka yang diikuti huruf Kapital yang sama arah horisontal (baris) dan angka yang diikuti huruf kecil yang sama arah vertikal (kolom) tidak berbeda nyata berdasarkan hasil Uji Duncan taraf nyata $5 \%$.

Tinggi tanaman menurut Sitompul (2016) lebih banyak dipengaruhi faktor lingkungan diantaranya cahaya dan air. Berdasarkan deskripsi varietas tanaman selada TW LGR 14 memiliki tinggi rata-rata $19-21 \mathrm{~cm}$. Hasil pengamatan tinggi tanaman dibandingkan dengan deskripsi varietasnya menunjukkan gejala etiolasi. tinggi tetapi menunjukan gejala etiolasi yang dicirikan dengan pertumbuhan tinggi tanaman yang berlebihan. Tanari \& Vita (2017) menyatakan tanaman selada yang diberi naungan $50 \%$ lebih tinggi, tapi terkena etiolas. Etiolasi ini dipengaruhi oleh hormon auksin, di tempat rendah cahaya, auksin akan memacu pertumbuhan batang lebih tinggi namun tanaman menjadi lemah, batang tidak kokoh, daun kecil, dan tumbuhan tampak 
pucat. Gejala etiolasi terjadi karena ketiadaan atau kekurangan cahaya matahari.

Hasil pengukuran rata-rata intensitas cahaya di dalam screen house yaitu $328 \mu \mathrm{mol}$ $\mathrm{m}^{-2} \mathrm{~s}^{-1}$ intensitas cahaya yang masuk ke dalam screen house lebih rendah dari kebutuhan intensitas cahaya matahari yang diperlukan oleh tanaman selada antara 400$600 \mu \mathrm{mol} \mathrm{m} \mathrm{m}^{-1}$ (Fu et al., 2012). Intensitas matahari yang kurang terpenuhi selama pertumbuhan menyebabkan gejala etiolasi yaitu penambahan tinggi secara berlebihan.

Hasil penelitian Olle (2017) menunjukkan pemberian pupuk Si pada tanaman selada dapat meningkatkan tinggi tanaman dibandingkan tanpa penambahan pupuk Si. Aplikasi ESSP 30 ppm pada konsentrasi $\mathrm{N}$ total 100 ppm menunjukkan tinggi tanaman tertinggi. Pada konsentrasi $\mathrm{N}$ total lebih rendah (100 ppm) penambahan pupuk Si dapat meningkatkan pertumbuhan tanaman. Pertumbuhan tinggi tanaman tanpa aplikasi Si akan menurun apabila diberikan $\mathrm{N}$ total >= 300 ppm.

\section{Luas daun $\left(\mathrm{cm}^{2}\right)$}

Hasil analisis varians (Tabel 1) menunjukkan parameter luas daun tidak dipengaruhi faktor ESSP dan faktor $\mathrm{N}$ total secara mandiri maupun pengaruh interaksi. Rata-rata luas daun yang dihasilkan semua taraf perlakuan yaitu 762 cm- 1.012 cm (Gambar 2).

Peningkatan konsentrasi $\mathrm{N}$ total 100-300 ppm tidak berpengaruh nyata meningkatkan luas daun. Kondisi ini diduga konsentrasi $\mathrm{N}$ total $100 \mathrm{ppm}$ pada formulasi nutrisi hidroponik masih dapat memenuhi kebutuhan unsur $\mathrm{N}$ tanaman. Menurut Mason (2014) tanaman dapat tumbuh pada $\mathrm{N}$ total minimum $50 \mathrm{ppm}$. Hasil penelitian Mahlangu et al. (2016) menunjukkan bahwa peningkatan luas daun terjadi pada konsentrasi N 90-120 ppm. Tanaman yang terpenuhi kebutuhan $\mathrm{N}$-nya dapat menjaga proses fotosintesis agar tetap berjalan.

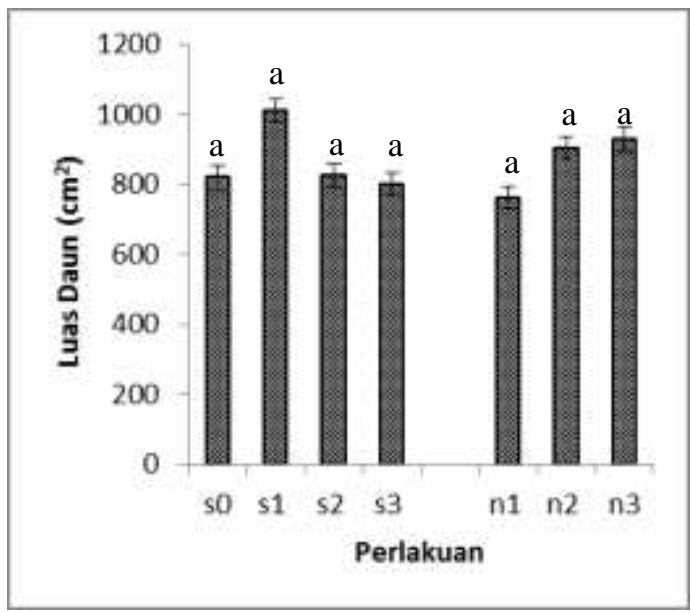

Keterangan: $\mathrm{s} 0=0 \mathrm{ppm}, \mathrm{s} 1=30 \mathrm{ppm}, \mathrm{s} 2=60 \mathrm{ppm}$, $\mathrm{s} 3=90 \mathrm{ppm}$ ESSP; $\mathrm{n} 1=100 \mathrm{ppm}, \mathrm{n} 2=200 \mathrm{ppm}$, n3=300 ppm N total. kolom batang yang ditandai huruf kecil yang sama tidak berbeda nyata berdasarkan uji Duncan taraf 5\%.

Gambar 2 Grafik rata-rata luas daun pada setiap taraf perlakuan

\section{Berat kering Tanaman (g)}

Hasil analisis varians (Tabel 1) menunjukkan bahwa Konsentrasi Si yang berasal dari ESSP (30-90 ppm) tidak berinteraksi dengan konsentrasi $\mathrm{N}$ total pada taraf 100-300 ppm. Faktor ESSP dan Faktor $\mathrm{N}$-total berpengaruh secara mandiri terhadap peningkatan berat kering tanaman. Berat kering tanaman merupakan indikator yang digunakan untuk mengukur hasil proses fisiologis tanaman dalam membentuk biomassa selama fase pertumbuhannya (Sitompul, 2016).

Interaksi yang diharapkan antara konsentrasi ESSP dan N-total terhadap peningkatan biomassa pada penelitian ini tidak terjadi diduga karena intensitas cahaya yang kurang dari kebutuhan minimum 400 umol $\mathrm{m}^{-2} \mathrm{~s}^{-1}$. Menurut Saito et al. (2010) intensitas cahaya mempengaruhi berat kering tanaman. Berat kering terbentuk dari 
proses fotosintesis ketersediaan sinar matahari, air dan unsur hara yang cukup akan meningkatkan hasil fotosintat.

Hasil analisis Duncan pada taraf $\alpha=5 \%$ (Gambar 3) pengaruh aplikasi ESSP 30 ppm berbeda nyata dengan perlakuan tanpa aplikasi ESSP. Taraf perlakuan konsentrasi $\mathrm{N}$ total 200 ppm berbeda nyata dengan perlakuan $\mathrm{N}$ total $100 \mathrm{ppm}$. Secara mandiri masing-masing taraf mempengaruhi pembentukan biomassa tanaman. Konsentrasi N-total $200 \mathrm{ppm}$ dapat memenuhi kebutuhan tanaman selama fase pertumbuhan. Unsur $\mathrm{N}$ dibutuhkan tanaman dalam pembentukan asam amino, protein dan klorofil (Aini \& Azizah, 2018).

Penambahan Si melalui pemberian ESSP 30 ppm secara nyata meningkatkan pembentukan biomassa tanaman dibandingkan tanpa pemberian ESSP. Unsur Si dapat meningkatkan serapan $\mathrm{N}$ tanaman dan memberikan tambahan unsur $\mathrm{N}, \mathrm{P}$ dan $\mathrm{K}$ yang terkandung dalam ESSP (Greger, et al., 2018).

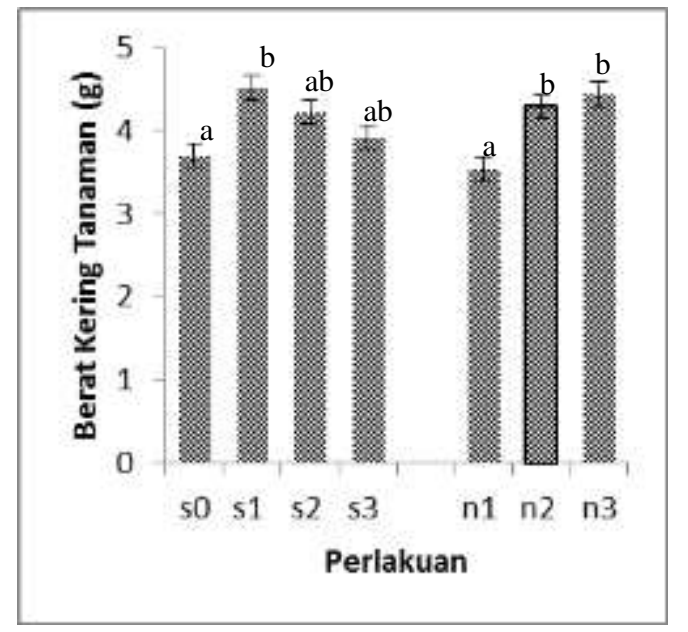

Keterangan: $\mathrm{s} 0=0 \mathrm{ppm}, \mathrm{s} 1=30 \mathrm{ppm}, \mathrm{s} 2=60 \mathrm{ppm}$, $\mathrm{s} 3=90 \mathrm{ppm}$ ESSP; $\mathrm{n} 1=100 \mathrm{ppm}, \mathrm{n} 2=200$ ppm, n3 $=300$ ppm N total. kolom batang yang ditandai huruf kecil yang sama tidak berbeda nyata berdasarkan uji Duncan taraf 5\%.

Gambar 3 Grafik Rata-rata Berat Kering Tanaman pada Masing-masing Taraf Perlakuan

\section{Berat Segar Tanaman (g)}

Berat segar tanaman merupakan indikator pertumbuhan tanaman sekaligus komponen hasil panen tanaman selada. Hasil analisis varians (Tabel 1) menunjukkan tidak terdapat interaksi antara konsentrasi ESSP dan $\mathrm{N}$-total terhadap berat segar tanaman.

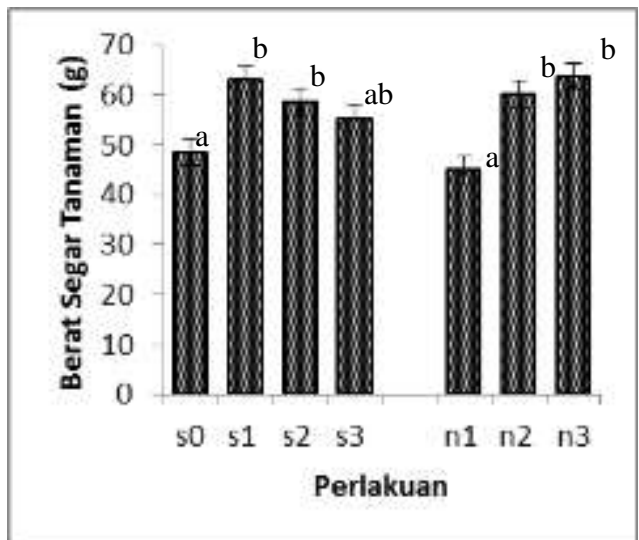

Keterangan: $\mathrm{s} 0=0 \mathrm{ppm}, \mathrm{s} 1=30 \mathrm{ppm}, \mathrm{s} 2=60 \mathrm{ppm}$, s3=90 ppm ESSP; n1= 100 ppm, n2=200 ppm, $\mathrm{n} 3=300 \mathrm{ppm} N$ total. kolom batang yang ditandai huruf kecil yang sama tidak berbeda nyata berdasarkan uji Duncan taraf $5 \%$.

Gambar 4 Grafik rata-rata berat segar pada setiap taraf perakuan

Aplikasi konsentrasi ESSP dan konsentrasi $\mathrm{N}$-total berpengaruh secara mandiri. Hasil uji Duncan (Gambar 4) mulai menunjukkan peningkatan berat segar terjadi pada kosentrasi ESSP 30 ppm dan konsentrasi Ntotal 200 ppm. Hasil penelitian mengonfirmasi hasil penelitian sebelumnya dari Egilla \& Ikem (2010) bahwa peningkatan $\mathrm{N}$-total 200 ppm pada tanaman selada meningkatkan berat segar tanaman. Penambahan ESSP 30 ppm meningkatkan berat segar tanaman karena $\mathrm{Si}$ berperan dalam meningkatkan serapan hara tanaman (Greger, Landberg \& Vaculík, 2018). Secara visual tampilan tanaman pada konsentrasi 30 ppm dan N 200 ppm (Gambar 5 g, h dan i). 


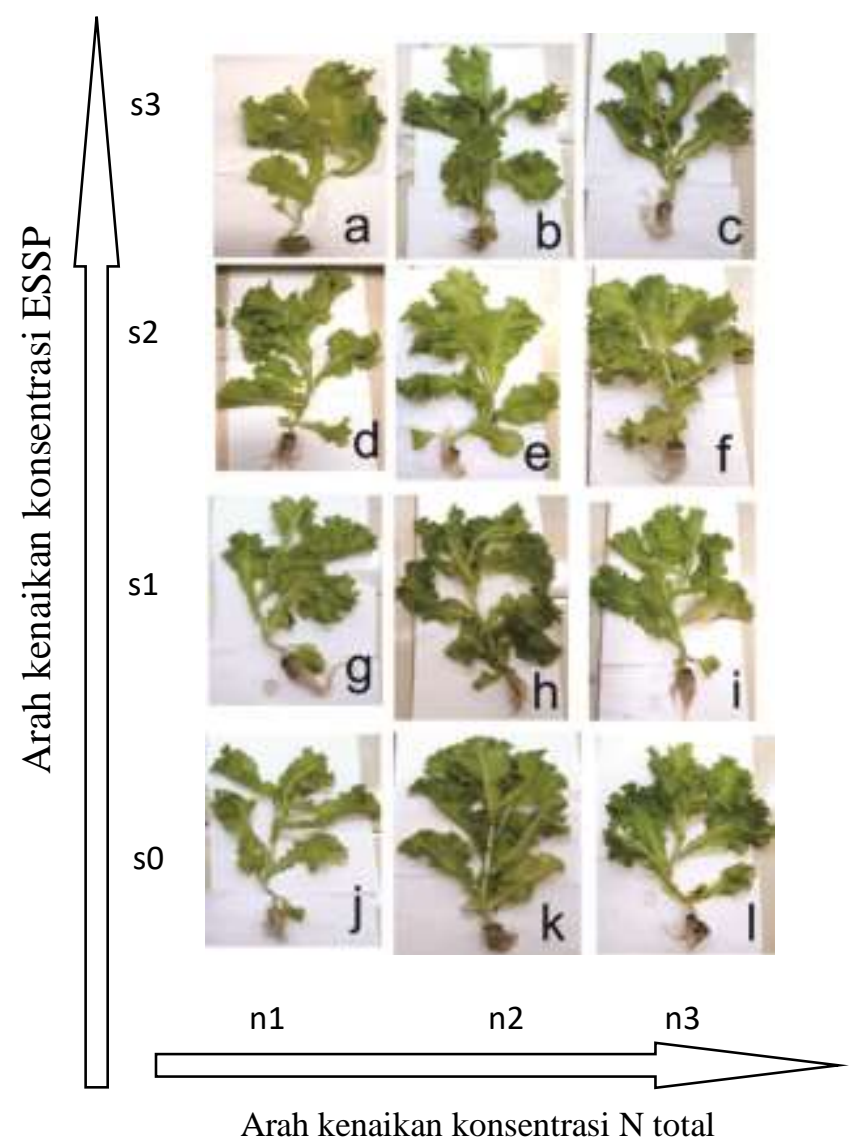

Keterangan: $\mathrm{s} 0=0$ ppm, s1=30 ppm, s2= 60 ppm, s3=90 ppm ESSP; n1= 100 ppm, n2=200 ppm, n3=300 ppm $\mathrm{N}$ total.

Gambar 5 Grafik konsentrasi nitrat pada daun selada berdasarkan taraf masing-masing faktor konsentrasi ekstrak silika sekam padi dengan konsentrasi $\mathrm{N}$ total AB Mix

Hubungan berat kering dan berat segar tanaman (Gambar 6) ditunjukkan oleh diagram pencar dua sumbu taraf perlakuan lainnya selain taraf perlakuan yang ditandai lingkaran merah berat segar dan berat kering berada dalam satu titik berdekatan yang artinya peningkatan berat segar berbanding lurus dengan pembentukan biomassa tanaman kondisi tersebut sesuai dengan pernyataan Sitompul (2016) yang menyatakan berat segar dapat digunakan untuk mengambarkan berat kering tanaman apabila hubungannya linier.

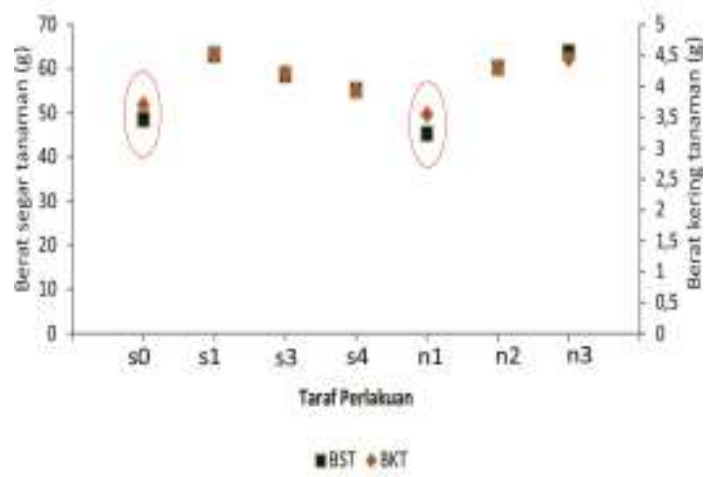

Keterangan: $\mathrm{s} 0=0 \mathrm{ppm}, \mathrm{s} 1=30 \mathrm{ppm}, \mathrm{s} 2=60 \mathrm{ppm}$, $\mathrm{s} 3=90 \mathrm{ppm}$ ESSP; n1= $100 \mathrm{ppm}, \mathrm{n} 2=200 \mathrm{ppm}$, n3=300 ppm N total.

Gambar 6 Diagram pencar dua sumbu berat segar tanaman dan berat kering tanaman pada setiap taraf perlakuan 
Berat kering yang terbentuk pada perlakuan tanpa aplikasi ESSP dan $\mathrm{N}$-total 100 ppm adalah $\pm 8 \%$ dari berat segarnya sedangkan taraf perlakuan lainya berat kering yang terbentuk rata-rata $\pm 7 \%$. Peningkatan berat kering tanaman dalam kondisi ketersediaan $\mathrm{N}$ terbatas merupakan anomali namun kondisi ini pernah terjadi pada penelitian Tolley and Mohammadi (2020) varietas gandum Opta pada kondisi ketersediaan hara $\mathrm{N}$ rendah berat kering tajuknya $1,80 \mathrm{~g}$ tidak menurun melainkan lebih tinggi dibandingkan dengan varietas yang ditanam dengan ketersediaan hara $\mathrm{N}$ tinggi $(1,74 \mathrm{~g})$. Peningkatan berat kering pada tanaman yang kondisi $\mathrm{N}$ tersedianya rendah diduga disebabkan oleh peningkatan photosynthetic nitrogen use efficiency
(PNUE) (Durand \& Goldstein, 2001; Nguyen et al., 2003).

\section{Konsentrasi Nitrat}

Hasil analisis kandungan nitrat $\left(\mathrm{NO}_{3}{ }^{-}\right)$ pada daun selada (Gambar 6) diperoleh hasil kandungan nitrat tertinggi $2.642 \mathrm{ppm}$ pada perlakuan $\mathrm{N}$-total $300 \mathrm{ppm}$ tanpa aplikasi ESSP dan terendah pada $\mathrm{N}$-total 100 ppm tanpa aplikasi ESSP. Beberapa negara di Eropa seperti negara Jerman memiliki batasan untuk produk selada segar yang dipasarkan kandungan nitrat tidak melebihi 2.500 ppm sedangkan negara Belgia membatasi kandungan nitrat pada selada tidak melebihi 3.500 ppm (Santamaria, 2006).

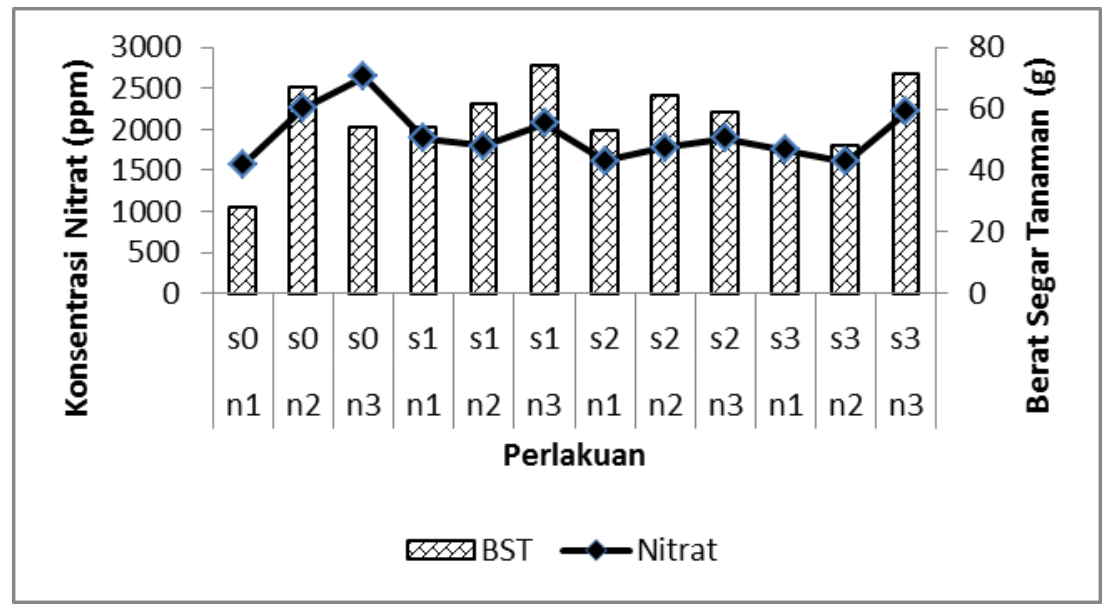

Keterangan: $\mathrm{s} 0=0 \mathrm{ppm}, \mathrm{s} 1=30 \mathrm{ppm}, \mathrm{s} 2=60 \mathrm{ppm}, \mathrm{s} 3=90 \mathrm{ppm}$ ESSP; $\mathrm{n} 1=100 \mathrm{ppm}, \mathrm{n} 2=200 \mathrm{ppm}, \mathrm{n} 3=300$ ppm $\mathrm{N}$ total.

Gambar 7 Grafik konsentrasi nitrat terhadap berat segar tanaman pada setiap taraf perlakuan

Kandungan nitrat pada penelitian ini sebagian besar lebih rendah dari ambang batas $2.500 \mathrm{ppm}$ kecuali perlakuan $\mathrm{N}$-total 300 ppm tanpa aplikasi ESSP. Menurut Gairola et al. (2009) peningkatan pupuk Nitrogen meningkatkan konsentrasi nitrat pada jaringan tanaman. Faktor lainnya yang mempengaruhi kandungan nitrat pada jaringan tanaman adalah intensitas cahaya.
Konsentrasi $\mathrm{N}$-total $300 \mathrm{ppm}$ yang dikombinasikan dengan aplikasi ESSP 30-90 ppm dapat menurunkan kandungan Nitrat Selada. Konsentrasi nitrat terendah 1.887 ppm dengan $\mathrm{N}$ total $300 \mathrm{ppm}$ dapat diperoleh dengan mengaplikasikan $60 \mathrm{ppm}$ ESSP namun dengan aplikasi ESSP 30 ppm rata-rata kandungan nitrat yaitu 2.076 ppm. 
Hasil analisis nitrat ini memberikan rekomendasi konsentrasi $\mathrm{N}$ total apabila budidaya hiroponik tanpa aplikasi ESSP $\mathrm{N}$ total yang direkomendasikan 200 ppm. Sedangkan dengan aplikasi ESSP 30 ppm pada tanaman selada konsentrasi $\mathrm{N}$-total yang digunakan pada tanaman hidroponik lebih lebar intervalnya yaitu 100-300 ppm. Dengan mempertimbangkan parameter pertumbuhan tanaman lainnya tinggi tanaman, luas daun, berat kering, berat segar tanaman dan kandungan nitrat. Aplikasi ESSP 30 ppm pada N-total 200 ppm merupakan rekomendasi pemberian nutrisi hidroponik yang dapat memenuhi kualitas hasil panen dan standar keamanan pangan bagi konsumen.

\section{SIMPULAN}

1. Interaksi konsentrasi ekstrak silika sekam padi (ESSP) dan konsentrasi $\mathrm{N}$ total hanya terjadi pada parameter tinggi tanaman sedangkan parameter berat kering, berat segar tanaman dipengaruhi secara mandiri oleh masingmasing faktor perlakuan. Parameter luas daun tidak dipengaruhi oleh kedua faktor perlakuan.

2. Aplikasi ESSP $30 \mathrm{ppm}$ dapat meningkatkan hasil panen $28 \%$ lebih tinggi dan kandungan nitrat $12 \%$ lebih rendah pada $\mathrm{N}$ total $100-300 \mathrm{ppm}$.

\section{UCAPAN TERIMAKASIH}

Penulis ucapkan terima kasih ke pada dan semua pihak yang telah membantu dalam penyelesaian penelitian ini.

\section{DAFTAR PUSTAKA}

Aini, N. and Azizah, N. (2018) Teknologi Budidaya Tanaman Sayuran Secara
Hidroponik. Malang: UB Press.

Anjana, Umar, S. and Iqbal, M. (2007) 'Nitrate accumulation in plant, factors affecting the process, and human health impacts. A review', Agronomy for Sustainable Development, 27(1), pp. 4547. doi: 10.1051/agro.

Dobermann, A. and Fairhurst, T. (2000) Rice: nutrient disorders \& nutrient management, Handbook Series. Available at:

http://books.google.com/books?id=VkJxfFhkaUC\&pgis=1.

Durand, L. Z. and Goldstein, G. (2001) 'Photosynthesis, photoinhibition, and nitrogen use efficiency in native and invasive tree ferns in Hawaii', Oecologia, 126(3), pp. 345-354. doi: 10.1007/s004420000535.

Egilla, J. N. and Ikem, A. (2010) 'Influence of Nutrient Source and Growing Environment on Tissue Elemental Concentration and Yield of Cos Lettuce in Hydroponic Culture', International Journal of Vegetable Science, 17(1), pp. 83-103. doi: 10.1080/19315260.2011.536070.

Frasetya, B. et al. (2019) 'Utilization of rice husk silicate extract to improve the productivity of paddy Ciherang cultivar', Bulgarian Journal of Agricultural Science, 25(3), pp. 499-505.

Frasetya, B. et al. (2021) 'The Effect of Various Total Nitrogen ( Total-N ) Concentrations in Hydroponic Nutrient on The Growth of Kailan Crop ( Brassica oleraceae L .)', in Proceedings of the 1st International Conference on Islam, Science and Technology, ICONISTECH 2019, 11-12 July 2019, Bandung, Indonesia. Bandung, West Java, pp. 1-6. doi: http://dx.doi.org/10.4108/eai.11-72019.2297416 .

Frasetya, B., Taofik, A. and Firdaus, R. K. 
(2018) 'Evaluasi Variasi Nilai Electrical Conductivity Terhadap Pertumbuhan Tanaman Selada ( Lactuca sativa L .) pada Sistem NFT', Jurnal Agro, 5(2), pp. 95102.

Frasetya, B., Taofik, A. and Sholehah, M. (2019) 'The evaluation of various nutrient formulation on the growth of lettuce ( Lactuca sativa Var . Arista ) in hydroponic raft system at tropic region', Journal of Physics: Conference Series, 1402(3), pp. 1-7. doi: 10.1088/17426596/1402/3/033025.

Fu, W. et al. (2012) 'Effects of different light intensities on anti-oxidative enzyme activity, quality and biomass in lettuce', Horticultural Science, 39(3), pp. 129-134. doi: 10.17221/192/2011-hortsci.

Gairola, S., Umar, S. and Suryapani, S. (2009) 'Nitrate accumulation, growth and leaf quality of spinach beet (Beta vulgaris Linn.) as affected by NPK fertilization with special reference to potassium', Indian Journal of Science and Technology, 2(2), pp. 35-40. doi: 10.17485/ijst/2009/v2i2/29390.

Gottardi, S. et al. (2012) 'Beneficial effects of silicon on hydroponically grown corn salad (Valerianella locusta (L.) Laterr) plants', Plant Physiology and Biochemistry. Elsevier Masson SAS, 56, pp. 14-23. doi: 10.1016/j.plaphy.2012.04.002.

Greger, M., Landberg, T. and Vaculík, M. (2018) 'Silicon influences soil availability and accumulation of mineral nutrients in various plant species', Plants, 7(2), pp. 116. doi: $10.3390 /$ plants 7020041.

Haynes, R. J. (2017) 'The nature of biogenic $\mathrm{Si}$ and its potential role in Si supply in agricultural soils', Agriculture, Ecosystems and Environment. Elsevier, 245(April), pp. 100-111. doi: 10.1016/j.agee.2017.04.021.
Ikemoto, Y., Teraguchi, M. and Kobayashi, Y. (2002) 'Plasma Levels of Nitrate in Congenital Heart Disease: Comparison with Healthy Children', Pediatric Cardiology, 23(2), pp. 132-136. doi: 10.1007/s00246-001-0036-9.

Mahlangu, R. I. S. et al. (2016) 'Lettuce (Lactuca sativa L.) growth, yield and quality response to nitrogen fertilization in a non-circulating hydroponic system', Journal of Plant Nutrition, 39(12), pp. 1766-1775. doi: 10.1080/01904167.2016.1187739.

Nguyen, N. T. et al. (2003) 'Effect of nitrogen deficiency on biomass production, photosynthesis, carbon partitioning, and nitrogen nutrition status of Melaleuca and Eucalyptus species', Soil Science and Plant Nutrition, 49(1), pp. 99-109. doi: 10.1080/00380768.2003.10409985.

Olle, M. (2017) 'the Effect of Silicon on the Organically Grown Iceberg Lettuce Growth and Quality', Agraarteadus, 28(2), pp. 82-86. doi: https://dx.doi.org/10.15159/jas.17.06.

Saito, Y. et al. (2010) 'The effect of light quality on growth of lettuce', IFAC Proceedings Volumes (IFACPapersOnline). IFAC, 3(PART 1). doi: 10.3182/20101206-3-JP-3009.00052.

Santamaria, P. (2006) 'Nitrate in vegetables: Toxicity, content, intake and EC regulation', Journal of the Science of Food and Agriculture, 86(1), pp. 10-17. doi: 10.1002/jsfa.2351.

Sitompul, S. M. (2016) Analisis Pertumbuhan Tanaman. Malang: UB Press.

Suka, I. G. et al. (2008) 'Karakteristik silika sekam padi dari provinsi lampung yang diperoleh dengan metode ekstraksi', MIPA, 37(1), pp. 47-52.

Tanari, Y,. \& Vita, V. (2017). Pengaruh 
naungan dan berbagai media tanam terhadap pertumbuhan dan produksi tanaman selada (Lactuca sativa L.). Jurnal AgroPet 14 (2).

Tolley, S. and Mohammadi, M. (2020) 'Variation in root and shoot growth in response to reduced nitrogen', Plants, 9(2), pp. 1-16. doi: 10.3390/plants9020144.

Xie, Z. et al. (2014) 'Effects of silicon on photosynthetic characteristics of maize (Zea mays L.) on alluvial soil', Scientific World Journal, $2014 . \quad$ doi: 10.1155/2014/718716. 